\title{
The Effect of Non-Monetary Incentives \& Work Environment on Employee's Job Satisfaction
}

\author{
ABDULKHALEQ NADER QADER \\ Business administration department, Shaqlawa technical college, ERBIL POLYTECHNIC UNIVERSITY, IRAQ, \\ E-mail: abdulkhalqnadr@epu.edu.iq
}

\begin{abstract}
This study aimed to investigate the effect of Non-Monetary Incentives \& work environment on employee's job satisfaction. A Stratified random sample, which was chosen, consisted of 234 academic staff within Erbil Polytechnic University, of a population of 601 people. To achieve the objectives of the study, the analytical descriptive approach and SPSS were used. The results indicated that there is a positive statistically significant relationship between the study's two independent variables (non-monitory incentives, and the work environment), reveal that non-monetary incentives are positively correlated with job satisfaction. Also, the results show that employee non-monetary incentives have significant positive effects on employees' job satisfaction so non-monetary incentives have significant positive effects on employees' job satisfaction.
\end{abstract}

Keywords: Non-Monetary Incentives; Work environment; Employee's job satisfaction; Erbil Polytechnic University.

\section{JEL Classification: J}




\title{
El Efecto de los Incentivos no Monetarios y el Ambiente de Trabajo en la Satisfacción Laboral de los Empleados
}

ABDULKHALEQ NADER QADER

Business administration department, Shaqlawa technical college, ERBIL POLYTECHNIC UNIVERSITY, IRAQ, E-mail: abdulkhalqnadr@epu.edu.iq

\begin{abstract}
RESUMEN
El objetivo de este estudio era investigar el efecto de los incentivos no monetarios y el entorno laboral en la satisfacción laboral de los empleados. Se eligió una muestra aleatoria estratificada compuesta por 234 miembros del personal académico de la Universidad Politécnica de Erbil, de una población de 601 personas. Para alcanzar los objetivos del estudio, se utilizó el enfoque analítico descriptivo y el SPSS. Los resultados indicaron que existe una relación positiva y estadísticamente significativa entre las dos variables independientes del estudio (los incentivos no monetarios y el ambiente de trabajo), y revelan que los incentivos no monetarios están positivamente correlacionados con la satisfacción laboral. Además, los resultados muestran que los incentivos no monetarios de los empleados tienen efectos positivos significativos en la satisfacción laboral de los empleados, por lo que los incentivos no monetarios tienen efectos positivos significativos en la satisfacción laboral de los empleados.
\end{abstract}

Palabras claves: Incentivos no monetarios; Ambiente de trabajo; Satisfacción laboral de los empleados; Universidad Politécnica de Erbil.

Clasificación JEL: J 


\section{Introduction}

The human in their environment in which lives has a set of different needs and is constantly trying to search for the means or resources to meet those needs. These are either monitorial or nonmonitorial needs, whichever of the needs is saturated with a specific means or resource, and this resource causes the individual to motivate and satisfy and direct him to the desired goal.

Through the studies related to human behavior of the academic staff on the work environment at the organizations in Erbil, observed that the number of indicators which we may conclude some deficiencies in their systems and methods of incentives applied to their workers, especially for those workers at universities, whether they related to monitory incentives or non-monitory incentives, while it may reflect negatively on Job satisfaction, hence the idea of this research, which examines the role of non- monitory incentives and work environment in deepening the core values of the job satisfaction for the academic staff of EPU.

The goal of this article is to find those links that connect non-monetary incentives, work environment, and job satisfaction. To benefit from non-monetary incentives the environment must be the primary key to implementation. The work environment conditions will be supportive of a welfare work environment at any level of the university. University work is fundamentally a scientific activity. The primary goal of any university is to make a successful and shared educational staff, and this needs a great effort on the part of the administrations and academic staff, and this also needs to satisfy them in jobs so that they work seriously and with full efforts.

A lot of research believes that the work environment is a major reason for job satisfaction, and many discussions and exchanges of views depend on non-monitory incentives in a good and healthy workplace as the main reason for employee satisfaction and ultimately increase productivity.

For the purpose of achieving the goal and showing appropriate solutions to the research problem, a set of the following important questions have been formulated:

1. Are the EPU academic staffs satisfied with their jobs?

2. Are the EPU academic staffs satisfy with their work environment?

3. What is the relationship between non-monitory incentives and the work environment?

4. What is the relationship between non-monetary incentives and job satisfaction?

5. What is the relationship between the work environment and job satisfaction?

\section{Literature Review}

\subsection{Non-Monetary Incentives}

Non-monetary incentives program in organizations is visible as rewards provided in appreciation of a high level of achievement or performance such as customer care or peer support, which is they depend on achieving a predetermined goal" (Rose, 1998). it can see as an effective tool for compensating employees, thereby attracting, motivating, and retaining employees (Abdullah\&Wan, 2013). One of the most important factors that have a necessary role to satisfy employees to perform their work with all effort and sincerity (Chandrasekhar, 2011). Non-monetary incentives have an important role in the perception of the employee regarding the reward program in the workplace (Khan et al., 2013). Where it is one of the important pillars in the universities and one of the basic jobs of institutional work in order to encourage excellence in work and performance, without which cannot achieve the vision and mission of the university (Kassahun, 2010). Also when organizations are interested in non-monetary tools such as the opportunity of increasing holiday and family benefits, the employee may perceive the organization as a supporting and caring organization (Deperi et al., 2010). According to (Holmes \& Parker,2017) Incentives can achieve their goals only through the existence of a working mechanism and a specific system, with an extremely important component, which is credibility in application and implementation. 
Lillard, (1992), indicated that Incentives are the tools for outstanding performance so that the employee feels fair and faith at their works, The organizations have a comparison with the treatment of other employees in it, especially those belonging same group in work.

The literature on organizational behavior and human resource management suggested that nonmonetary incentives are the fact that effectively motivate employees. The spirit of incentives is to establish linkage with desired behavior and the outcome that makes the employee feel appreciated (Whetten \& Cameron, 2007).

Deeprose (1994) argues that a non-monetary incentive has a significant impact on employees" motivation and productivity. Effective use of non-monetary program results in improved performance of the organizations. Employees take non-monetary incentives as part of their feelings of value and appreciation and as a result, it increases employees " morale, which eventually increases the efficiency of organizations.

Danish \& Usman (2010), emphasized that when rewards and recognition programs are properly implemented, a good working environment is provided that motivates employees to achieve high performance. Murphy (2007) utilized an online survey to study the effects of monetary and nonmonetary incentives on labor turnover. The results of the study revealed that no significant difference was found in labor turnover. Jeffrey (2004) argued that several principles of social and cognitive psychology provide reasons to believe that employees may perceive non-monetary incentives to be more valuable than the retail value of that award in cash.

\subsection{Work environment}

The location is the main reason for completing the tasks, the work environment includes the physical geographical location as well as the immediate surroundings of the workplace, such as a construction site or office building (Massoudi \& Hamdi,2017). It usually includes other factors related to the workplace, such as air quality, noise level, perks, and fringe benefits for work like free childcare, unlimited coffee, or adequate parking (www.businessdictionary.com).

Ryan and Deci, (2000), argued that a widely accepted assumption is that a better workplace environment motivates employees and produces better results, the office environment can be described in terms of physical and behavioral components. An organization's physical environment and its design and layout can affect employee behavior in the workplace, Brill (1990) estimates that improvements in the physical design of the workplace may result in a 5-10 percent increase in employee productivity, He argued that increasing the organization's physical layout is designed around employee needs in order to maximize productivity and satisfaction.

Also, the term work environment is used to describe the surrounding conditions in which an employee operates. It can be composed of physical conditions, such as office temperature, or equipment, like personal computers. It can also be related to factors such as work processes or procedures (Chandrasekar,2011).

\subsection{Employee's Job Satisfaction}

Job satisfaction is represented a key concept in manufacturing and organizational psychology and has been related to the number of affirmative variables like job motivation, job performance, organizational citizenship behavior, and life satisfaction (Kara, 2020). Job satisfaction entails how people feel about the job they engage in and its different aspects. Hancer \& George, (2003) contends that job satisfaction explains the extent to which people like (satisfaction) or dislike (dissatisfaction) the job they do. Jung \& Suh,(2019) indicated that if an employee enjoys a high level of job satisfaction, his or her tendency to look for another job and that of leaving an organization decrease. It is likely that the increases in the job satisfaction of an employee experience, became the factor for rise the positive attitude toward the jobs and commitment to the organization (Sarwar and Abugre, 2013). Mentioned (Hulin \& Judge, 2003) that job satisfaction contains multidimensional rational responses to one's job that has responses components in the cognitive (evaluative), affective (or 
emotional), and behavioral dimensions. According to (Celik, 2011) in the classical job satisfaction model, employee consciousness of the job that one attracts in was the main focus. However, satisfaction and dissatisfaction are not bounded to the quality of the job that one does but also depends on the perceptions, attitude, and expectations towards the job. The wise managers give priority to employee job satisfaction due to the relevance (Yang \& Kassekert, 2010). The importance of employees cannot be underestimated as they remain planners, designers, and implementers of organizational progress towards achieving its objectives (Senyucel, 2009). according to a study (Lee \& Dahinten,2020) that applicated of

The sample consisted of 113 perioperative nurses working in acute-care hospitals argued that one possible strategy is to hold regular staff meetings where nurses feel safe to raise their concerns and make suggestions to improve patient care or the working environment. Patterson (2010) argues that what gives satisfaction differs from one employee to another; some employees may receive a high degree of satisfaction in their jobs than from the work itself, some might receive the greatest level of satisfaction from their jobs from relationships with supervisors and coworkers while pay package might retain some employees in their jobs though they considered the jobless meaningful and receive meager satisfaction from the job facets (saeed et al 2019). Furthermore, the relationship between job satisfaction and employee engagement has been documented in the literature. Indeed, job satisfaction and engagement are essential ingredients for organizational sustainability.

\subsection{Erbil Polytechnic University}

Erbil Polytechnic University (EPU) is a public university, located in Erbil City of the Kurdistan Region of Iraq. Erbil Polytechnic University was founded in 1993 by the Kurdistan National Council and was opened in 1996 under the name of 'Foundation of Technical Institutes (Kawa Sherwani,2020). When the Technical colleges were opened, its name was changed to the 'Foundation of Technical Studies. It later became the Erbil Polytechnic University in 2012, embracing 5 colleges and 6 technical institutes includes Erbil Technical Engineering College, Erbil Administration Technical College, Erbil Technical health college, Erbil Technology college, Shaqlawa Technical college, Erbil Medical Institute, Erbil Technical Administration Institute, Koya Technical Institute, Soran Technical Institute, Khabat Technical Institute, Choman Technical Institute (Kawa Sherwani,2020).

Erbil Polytechnic University is a scientific governmental academy that aims at educating technical qualified people in the various specialties to meet the needs of the society, as a non-profitable center of education. It develops human capacities and resources in technical fields for the graduates of the preparatory Schools and educating technical qualified people about the marketing needs (Bhatti et al 2018). It provides advisory services in all advisory councils. It supports scientific research and innovations to reach the profession and new ideas on an advanced level. It has Research Centers / Research laboratories include :( Biomedical Research Laboratory, Computer Science and Information Technology Research Laboratory, and Solar Energy Laboratory). also, EPU has 601 MA and Ph.D. degree holders. And about 1865 Administrative employees (Staff Members), it provides a master's degree and diploma (https://epu.edu.iq/about-epu/).

\section{Methodology}

In this study, the quantitative approach in the form of cross-sectional or correlation research designed regression analysis was used as it appeared to be more appropriate in exploring the impact of non-monetary incentives and work environment on job satisfaction in EPU's staff academy (figar.1). So to finding suitable answers for research questions and achieve the study goals, the following hypotheses can be examined through appropriate statistical equations using SPSS Software:

$\mathrm{H} 1$ : There is a positive relationship between non-monitory incentives and the work environment of staff academies of EPU's colleges and institutes. 
H2: The employee's job satisfaction is positively influenced by Non-monitory incentives of staff academies of EPU's colleges and institutes.

H3: The employee's Job satisfaction is positively influenced by the Work environment of staff academies of EPU's colleges and institute

Fig. 1. Hypothetical relationships between Non-monitory incentives, work environment, and employees' job satisfaction.

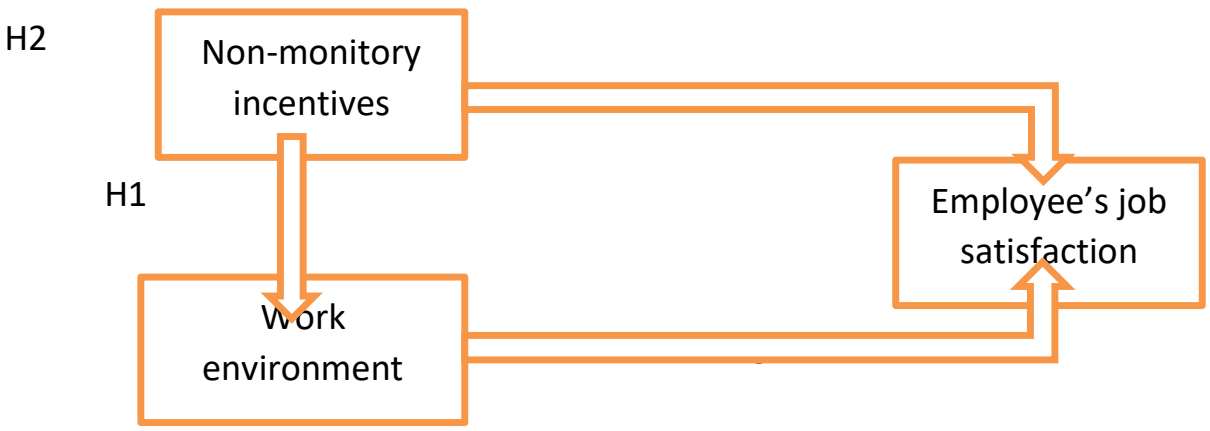

\subsection{Data collection tools}

In the data collection process, the questionnaire method was used. The questionnaire consists of four sections. The first section consists of six components related to demographic data and the second part is related to the Non-Monetary Incentives developed by Delic, et al (2014, August), which has been used, It consists of 9 items. The third section related to the work environment consisted of 14 items and, was developed by (Morgeson, \& Humphrey,2006), fourth section related to the job satisfaction scale was developed (Morgeson, \& Humphrey,2006) consists of 10 items.

The received data from the EPU's staff academic indicated that about 601 persons have MA and a Ph.D. degree in this university, they distributed on the 11 colleges and institutes. Questionnaires were distributed to a sample of 234 employees according to the rule of Krejcie and Morgan (1970). Of those, 201 were returned, resulting in (86\%) included in the data analysis.

\subsection{Measuring instruments}

The five-point Likert scale was utilized to evaluate the variables through their related answers. The validity and reliability of the questionnaire were tested using a sample of 65 respondents from 3 institutes of EPU. The participant understanding of the items was verified. Overall, the Cronbach's alpha across all 33 items was $(0,879)$, showing this questionnaire had high internal consistency and respondents understood all items well. Leech et al. (2005) and Nunnally and Brenstein (1994) also noted this about the questionnaire.

\subsection{Demographic characteristics}

Table .1 shows the largest and smallest proportion of the sample population belongs to the males $(60.69 \%)$ and females $(39.31 \%)$, respectively. This result is in good agreement with the nature of the group's work, suggesting that the female population is not actively involved in the academic staff, compared to the male population. This may be attributed to the dominating culture which does not support women to work in universities.

Table 1. Sample Employee gender factor

\begin{tabular}{|l|l|l|l|}
\hline Dimensions & Items & $\mathrm{N}$ & $\%$ \\
\hline \multirow{2}{*}{ Gender } & Male & 122 & 60.69 \\
\cline { 2 - 4 } & Female & 79 & 39.31 \\
\hline
\end{tabular}


Table 2, below shows that the majority of respondents in the sample ranged in age from 31 to 50 years, from 31 - 40 years $41-50$ years, is (30.34 \%) and (43.28\%) respectively.

Table .2. Sample Employee age factor

\begin{tabular}{|l|l|l|l|}
\hline Dimensions & Items & N & $\%$ \\
\hline \multirow{4}{*}{ Age } & $18-30$ & 25 & 12.43 \\
\cline { 2 - 5 } & $31-40$ & 61 & 30.34 \\
\cline { 2 - 5 } & $41-50$ & 87 & 43.28 \\
\cline { 2 - 4 } & 51 and above & 28 & 13.9 \\
\hline
\end{tabular}

According to Table .3, those with a master's degree constitute the largest proportion (57.21\%), Approximately (41.79\% of the population have a Ph.D. Degree, This result indicates that the EPU has witnessed a significant increase in the number of master and Ph.D. degrees over the past years.

Table .3. Sample Employee educational profile factor

\begin{tabular}{|l|l|l|l|}
\hline Dimensions & Items & N & $\%$ \\
\hline Education profile & Ph.D & 84 & 41.79 \\
\cline { 2 - 4 } & Master & 115 & 57.21 \\
\cline { 2 - 4 } & $\begin{array}{l}\text { Technical diploma (2years after } \\
\text { high school) }\end{array}$ & 2 & 0.99 \\
\hline
\end{tabular}

As for the information related to the employees' positions, we refer to them from Table (4), which shows that the average of staff are the lecturers in the sample and their percentage $(52.23 \%)$, And those who work as a middle and top administration are less and their proportion (31.84\%) (15.92\%) respectively.

Table 4. Sample Employee Job position factor

\begin{tabular}{|l|l|l|l|}
\hline Dimensions & Items & $\mathrm{N}$ & $\%$ \\
\hline \multirow{3}{*}{ job position } & Lecturer & 105 & 52.23 \\
\cline { 2 - 5 } & Middle level manger & 64 & 31.84 \\
\cline { 2 - 5 } & Top manager & 32 & 15.92 \\
\hline
\end{tabular}

Table (5) shows that those who work in this university for more than 10 years are the majority It is possible this leads to the policy of this university, who started with work in the region have appointed the staff and keep them for a long time to benefit from their experiences, The EPU also interested to incentives so employees like to stay in for a long time.

Table .5. Sample Employee Years with this company factor

\begin{tabular}{|l|l|l|l|}
\hline Dimensions & Items & $\mathrm{N}$ & $\%$ \\
\hline \multirow{3}{*}{$\begin{array}{l}\text { Years of work in the } \\
\text { university }\end{array}$} & 1 to 5 years & 3 & 1.49 \\
\cline { 2 - 4 } & 6 to 10 years & 56 & 27.6 \\
\cline { 2 - 5 } & More than 10 years & 142 & 70.64 \\
\hline
\end{tabular}

\subsection{Descriptive statistics}

To answer our research questions, all items were tested using means and standard deviations.

As shown in Table 6, the mean of non-monitory incentive levels ranged from 4.10 to 4.34 , and the overall mean was (4.18), with a standard deviation of (0.63) this showing that EPU's academic staff have a good understanding of non-monitory incentives.

The mean value for the work environment varied from 4.04 to 4.36 , and the pivot was the average score of 4.21 with the standard division of (0.69). These results show that the academic staff of EPU was satisfying their work environment. 
Measures of job satisfaction ranged from 4.08 to 4.36 , and the pivot was the average score of 4.23. Standard division of 0.66 , thus demonstrating that academic staff in EPU is satisfied with their jobs.

Table 6. Descriptive statistics

\begin{tabular}{|c|c|c|c|c|}
\hline $\begin{array}{l}\frac{\mathscr{0}}{0} \\
\frac{\sqrt{0}}{\frac{\pi}{2}} \\
>\end{array}$ & & Items & 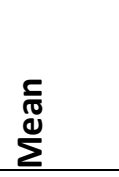 & 旁 \\
\hline \multirow{9}{*}{ 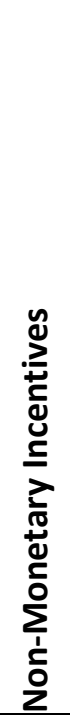 } & 1 & There is a possibility for advancement to senior positions. & 4.19 & .57 \\
\hline & 2 & $\begin{array}{l}\text { Potential exists for additional training in accordance with the } \\
\text { requirements of the job. }\end{array}$ & 4.10 & .61 \\
\hline & 3 & $\begin{array}{l}\text { Our university supports and evaluates the proper acquisition } \\
\text { of professional knowledge of their staff. }\end{array}$ & 4.11 & .62 \\
\hline & 4 & There is flexibility in the use of breaks. & 4.19 & .51 \\
\hline & 5 & There is flexibility in terms of timing of annual leave. & 3.98 & .62 \\
\hline & 6 & $\begin{array}{l}\text { Management is organizing an informal gathering of } \\
\text { employees. }\end{array}$ & 4.21 & .49 \\
\hline & 7 & $\begin{array}{l}\text { Academic staff receives regular feedback about their work } \\
\text { performance. }\end{array}$ & 4.34 & .79 \\
\hline & 8 & $\begin{array}{l}\text { Academic staff with high performance are publicly rewarded } \\
\text { and praised. }\end{array}$ & 4.26 & .69 \\
\hline & 9 & $\begin{array}{l}\text { Academic staffs are adequately familiar with the business } \\
\text { policy of the university. }\end{array}$ & 4.28 & .78 \\
\hline \multicolumn{3}{|c|}{ Average score } & 4.18 & .63 \\
\hline \multirow{14}{*}{ 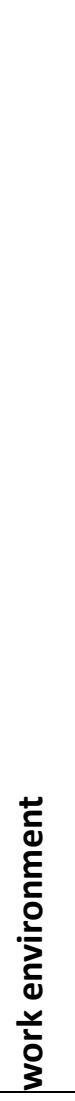 } & 1 & $\begin{array}{l}\text { Relations between university president /assists / deans / } \\
\text { head of departments / supervisors and their subordinates } \\
\text { are good. }\end{array}$ & 4.08 & .57 \\
\hline & 2 & I feel comfortable asking a colleague for professional help. & 4.27 & .66 \\
\hline & 3 & There is a high degree of trust among employees. & 4.36 & .77 \\
\hline & 4 & $\begin{array}{l}\text { Frequent internal conflicts and quarrels are not typical for } \\
\text { our university. }\end{array}$ & 4.21 & .73 \\
\hline & 5 & $\begin{array}{l}\text { Interpersonal relationships at work are not only formal but } \\
\text { also informal. }\end{array}$ & 4.18 & .67 \\
\hline & 6 & $\begin{array}{l}\text { The job activities are greatly affected by the work of other } \\
\text { people. }\end{array}$ & 4.24 & .60 \\
\hline & 7 & The job requires a variety of skills. & 4.14 & .79 \\
\hline & 8 & $\begin{array}{l}\text { The job requires spending a great deal of time with people } \\
\text { outside my organization. }\end{array}$ & 4.25 & .60 \\
\hline & 9 & The job requires a great deal of muscular strength. & 4.24 & .60 \\
\hline & 10 & The work place is free from excessive noise. & 4.34 & .63 \\
\hline & 11 & $\begin{array}{l}\text { The climate at the workplace is comfortable in terms of } \\
\text { temperature and humidity. }\end{array}$ & 4.28 & .85 \\
\hline & 12 & My job requires me to analyze a lot of information. & 4.25 & .69 \\
\hline & 13 & $\begin{array}{l}\text { The job involves the use of complex equipment or } \\
\text { technology }\end{array}$ & 4.04 & .98 \\
\hline & 14 & $\begin{array}{l}\text { Employees are willing to work together in order to achieve } \\
\text { the university goals. }\end{array}$ & 4.13 & .63 \\
\hline \multicolumn{3}{|c|}{ Average score } & 4.21 & .69 \\
\hline
\end{tabular}




\begin{tabular}{|c|c|c|c|c|}
\hline \multirow{10}{*}{ 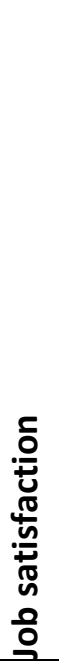 } & 1 & My job gives me a lot of satisfaction. & 4.08 & .57 \\
\hline & 2 & My job is very meaningful for me. & 4.27 & .66 \\
\hline & 3 & I'm enthusiastic about my work. & 4.36 & .77 \\
\hline & 4 & My job gives me the opportunity to show my worth. & 4.21 & .73 \\
\hline & 5 & The job allows me to plan how I do my work. & 4.18 & .67 \\
\hline & 6 & $\begin{array}{l}\text { The results of my work are likely to significantly affect the } \\
\text { lives of other people. }\end{array}$ & 4.24 & .60 \\
\hline & 7 & The job allows me to make a lot of decisions on my own. & 4.14 & .79 \\
\hline & 8 & $\begin{array}{l}\text { The job itself provides me with information about my } \\
\text { performance. }\end{array}$ & 4.25 & .60 \\
\hline & 9 & $\begin{array}{l}\text { I have the opportunity to develop close friendships in my } \\
\text { job. }\end{array}$ & 4.24 & .60 \\
\hline & 10 & $\begin{array}{l}\text { I receive feedback on my performance from my bosses in } \\
\text { my university. }\end{array}$ & 4.34 & .63 \\
\hline \multicolumn{3}{|c|}{ Average score } & 4.23 & .66 \\
\hline
\end{tabular}

\subsection{Test hypotheses of the study}

The Pearson correlation was used to find the relationship between research variables. Table (7) shows the results of this test. There is a significant positive relationship between the non - monitory incentives and work environment $\mathrm{R}=0,67^{* *}$.that is indicated to a strong correlation (Rajapaksa, D., et al., 2019). As a result, $\mathrm{H} 1$ was accepted.

Table 7. Correlations between non-monitory incentives and work environment:

\begin{tabular}{|l|l|c|c|}
\hline \multicolumn{2}{|l|}{} & $\begin{array}{c}\text { Non-monitory } \\
\text { incentives }\end{array}$ & $\begin{array}{c}\text { Work } \\
\text { environment }\end{array}$ \\
\hline non-monitory incentives & $\begin{array}{l}\text { Personal } \\
\text { correlation }\end{array}$ & 1 & $0,67^{* *}$ \\
\hline & Sig. (2-tailed) & & 0,00 \\
\hline & N & 201 & 201 \\
\hline Work environment & $\begin{array}{l}\text { Personal } \\
\text { correlation }\end{array}$ & $0,67^{* *}$ & 1 \\
\hline & Sig. (2-tailed) & 0,00 & 201 \\
\hline & N & 201 & \\
\hline
\end{tabular}

Source: researcher

To test the second hypothesis which states (The employee's job satisfaction is positively influenced by Non-monitory incentives in EPU's colleges and institutes), multiple regression analysis was used. As shown in Table (8) depending on the adjusted $R^{2}$, Non-monitory incentives can predict and explain $57 \%$ of the employee's Job satisfaction; It has a statistically significant effect on employee's Job satisfaction at $\alpha \leq .05$ ( $p<.001 ; F=115.3, R 2=0.58$ ). The coefficient of correlation (R) among all variables was 0,72 , indicating a strong correlation. As a result, $\mathrm{H} 2$ was accepted.

The results of multiple regression analysis were used to evaluating H3. as seen in the results of adjusted $R^{2}$ values employee's Job satisfaction is affected by Work environment conditions to an extent of $64 \%$, indicating that the Work environment has a statistically significant effect on employee's Job satisfaction at $\alpha \leq(0.05)\left(p<(0.001) ; F=111.98, R^{2}=0.64\right)$. The overall coefficient of correlation was (0.72), indicating strength in the relationship. Therefore, $\mathrm{H} 3$ was accepted. 
Table 8. Multiple Regression Analysis Test Results for Impact of non-monitory incentives and work environment on employee's job satisfaction

\begin{tabular}{|c|c|c|c|c|c|c|c|c|}
\hline & \multicolumn{8}{|c|}{ Employee's Job satisfactions } \\
\hline & $B$ & Beta & t- value & $\begin{array}{c}\text { Significance } \\
\text { level }\end{array}$ & $R$ & $R^{2}$ & Adjusted $\mathrm{R}^{2}$ & $F$ \\
\hline Non-monitory & \multirow{2}{*}{0,373} & \multirow{2}{*}{0,58} & \multirow{2}{*}{2,750} & \multirow{2}{*}{0,007} & \multirow{2}{*}{0,72} & \multirow{2}{*}{0,58} & \multirow{2}{*}{0,57} & \multirow{2}{*}{115,3} \\
\hline Incentives & & & & & & & & \\
\hline $\begin{array}{l}\text { Work } \\
\text { environment }\end{array}$ & 0,312 & 0,61 & 1,930 & 0,000 & 0,72 & 0,64 & 0,64 & 111,9 \\
\hline
\end{tabular}

Source: researcher

\section{Discussion And Conclusion}

This study attempts to find the relationship between non-monetary incentives, work environment, and job satisfaction in the EPU's staff academic. The non-monetary incentives and their impact and their relationship with other variables is a recent topic There are a few previous research on the relations with the work environment and job satisfaction, especially in Iraq. and this is an obstacle for the researcher to verify the accuracy of the findings of the study and compare them with the results of the study to answer the questions of the study, a set of hypotheses was formulated that reflects the answer of each hypothesis a question to explain the relationship between the research variables. The study reached a set of results that contributed to solving the problem of the study, answering its questions, and testing the validity of its hypotheses. Can be referred to the most important findings of the study based on the sample responses are as follows:

The results indicated that there is a positive statistically significant relationship between the study's two independent variables (non-monitory incentives, and the work environment) according to the result of $R=0,67$ with significance level $(0,00)$. This means that in the event of any change in monetary incentives, interprets $67 \%$ of the changes that occur in the work environment, and the rest of the changes are due to other reasons. This result coms with the finding of Rajapaksa, et al,. (2019) from their research Ander the address of that (Do monetary and non-monetary incentives influence environmental attitudes and behavior? Evidence from an experimental analysis).

Other finding in this research coming with the results of previous research Abdullah \& Wan, (2013) in their article of (Relationships of Non-Monetary Incentives, Job Satisfaction and Employee Job Performance) that is reveal that non-monetary incentives is positively correlated with job satisfaction. Therefore, the more positive an employee's level of non-monetary incentives, the more positive their attitude toward job satisfaction. The effect of employee non-monetary incentives and work environment on job satisfaction of staff academies of EPU's colleges and institutes,

Were two important aspects not contemplated in previous studies? Moreover, these results show that employee non-monetary incentives have significant positive effects on employees job satisfaction so as non-monetary incentives has significant positive effects on employees job satisfaction (Alghamdi et al 2021).

\subsection{Limitations and Suggestions for Future Research}

The EPU managers should focus on non-monitory incentives, and act to enhance the employee's job satisfaction of their university. University must try to develop motivation programs and a university's work environment through their serious interest in increasing the strength of the works. The EPU managers must not only focus on the monetary motivations system, but the non-monitory incentive system of their university is the most important so they must work to enhance the job satisfaction of their university by measuring incentives dimensions and strengthening them. The EPU managers can create an appropriate atmosphere in order to encourage their employees to move towards high satisfying and raise them by applying the dimensions of the incentives 
Also based on the findings, the following scientific recommendations can be formulated:

Future studies can re-test the same model of the study on a larger sample than Commercial and investment industry organizations in the other sector, such as similar competition markets the results of this study were consistent.

Future studies are bid to non-monitory incentives additional items, where the current study relied on only a small number of items.

The current study is based on the questionnaire as a single tool for data collection. It is not devoid of the probability of bias when filling it. Future studies are invited to use other research tools such as interviews and observation to reduce the degree of bias.

This research was carried out at a time of the spread of the Coronavirus, the researcher was not able to directly reach all of the respondents, and for this reason, the questionnaire was distributed via e-mail to the university's academic staff, most of whom did not return the questioners, and the researcher sent him back several times it due to delay this work for a long time, however, the researcher's spiral about his work came to a conclusion.

In this research, the researcher focused on finding the relationship and influence between the variables of the research in a simple and easy way, but future researches can work on establishing this relationship and influence in another way and applying the same title in the field of the other. Also, relates each of the variables this research with the other variable.

\section{References}

1. Abdullah, A. A., \& Wan, H. L. (2013). Relationships of non-monetary incentives, job satisfaction and employee job performance. International Review of Management and Business Research, 2(4), 1085.

2. Alam, M. S., Shaheed, A. A., Sahabuddin, M. \& Akter, S. (2013). Relationship between employee recognition and employee contribution in service industry. International Journal of Business and Marketing Management 1 (1), 1-8.

3. Alghamdi, A., Mehtab, T., Iqbal, R., Leeza, M., Islam, N., Hamdi, M., \& Shaikh, A. (2021). Automatic Classification of Monosyllabic and Multisyllabic Birds Using PDHF. Electronics, 10(5), 624.

4. Brill, M. (1990). Workspace design and productivity. Journal of Healthcare Forum, 35 (5), pp. 51-3.

5. Bhatti, S. K., Lali, M. I. U., Shahzad, B., Javid, F., Mangla, F. U., \& Ramzan, M. (2018). Leveraging the big data produced by the network to take intelligent decisions on flow management. IEEE Access, 6, 12197-12205.

6. Celik, M. (2011). A theoretical approach to the job satisfaction. Polish journal of management studies, 4, 7-14.

7. Chandrasekar, K. (2011). Workplace environment and its impact on organisational performance in public sector organisations. International journal of enterprise computing and business systems, 1(1), 1-19.

8. Danish, K., Rizwan Q. \& Usman A. (2010). Impact of reward and recognition on job satisfaction and motivation: An empirical study from Pakistan, International Journal of Business and Management,5(2), 159-167.

9. Deeprose, D. (1994). How to recognize and reward employees. New York: AMACOM.Depedri, S. Tortia, E. Carpita, M. (2010). Incentives, job satisfaction and performance: Empirical evidencein Italian social enterprises. European Research Institute on Cooperatives and Social Enterprises Working Papers No. 012/10.

10.Delic, A., Kozarevic, E., Peric, A., \& Civic, B. (2014, August). The monetary and non-monetary incentives impact on job satisfaction: Evidence from Bosnia and Herzegovina banking sector. In Annual Paris Business and Social Science Research Conference.

11.Depedri, S. Tortia, E. Carpita, M. (2010). Incentives, job satisfaction and performance: Empirical evidence 
12.Hancer, M., \& George, R. T. (2003). Job satisfaction of restaurant employees: An empirical investigation using the Minnesota Satisfaction Questionnaire. Journal of Hospitality \& Tourism Research, 27(1), 85-100.

13. Holmes, W. T., \& Parker, M. A. (2017). Communication: Empirically testing behavioral integrity and credibility as antecedents for the effective implementation of motivating language. International Journal of Business Communication, 54(1), 70-82.

14.Hulin, C. L., \& Judge, T. A. (2003). Job attitudes. Handbook of psychology, 255-276. in Italian social enterprises. European Research Institute on Cooperatives and Social Enterprises

15.Jeffrey, S. (2004). The benefits of tangible non-monetary incentives. University Of Chicago, Graduate School Of Business.p. 5

16.Jung, Y., \& Suh, Y. (2019). Mining the voice of employees: A text mining approach to identifying and analyzing job satisfaction factors from online employee reviews. Decision Support Systems, 123, 113074.

17.Kara, S. (2020). Investigation of Job Satisfaction and Burnout of Visual Arts Teachers. International Journal of Research in Education and Science, 6(1), 160-171.

18.Kassahun, T. (2010). Rethinking institutional excellence in Ethiopia: adapting and adopting the balanced scorecard (BSC) model. Journal of Business and Administrative Studies, 2(1), 22-53.

19. Kawa Sherwani, (2020) President of the University of his report on the Erbil Polytechnic University website, https://epu.edu.iq/about-epu/

20.Khan, I., Shahid, M., Nawab, S. \& Wali S. S. (2013). Infleunce of intrinsic and extrinsic rewards onemployee performance: The banking sector of Pakinstan. Academic Research International,4 (1),282-292.

21.Krejcie, R. V., \& Morgan, D. W. (1970). Determining sample size for research activities. Educational and psychological measurement, 30(3), 607-610.

22.Lee, S. E., MacPhee, M., \& Dahinten, V. S. (2020). Factors related to perioperative nurses' job satisfaction and intention to leave. Japan Journal of Nursing Science, 17(1), e12263.

23.Leech NL, Barrett KC, Morgan GA (2005) SPSS for intermediate statistics: Use and interpretation. Psychology Press.

24.Lillard, M. C. (1992). Fifty Jurisdictions in Search of a Standard: The Covenant of Good Faith and Fair Dealing in the Employment Context. Mo. L. REv., 57, 1233.

25.Massoudi, A. H., \& Hamdi, S. S. A. (2017). The Consequence of work environment on Employees Productivity. IOSR Journal of Business and Management, 19(01), 35-42

26.Morgeson, F. P., \& Humphrey, S. E. (2006). The Work Design Questionnaire (WDQ): developing and validating a comprehensive measure for assessing job design and the nature of work. Journal of applied psychology, 91(6), 1321.

27. Murphy, M. (2007). Incentive programs and labor turnover rate in hospital food service. A thesis submitted to Graduate school, Texas Woman"s university, USA.

28.Nunnally JC, Bernstein IH (1994) Validity. Psychometric theory: 99-132. Organ DW (1988) Organizational citizenship behavior: The good soldier syndrome. Lexington, MA: Lexington Books.

29.Patterson, E. S., \& Wears, R. L. (2010). Patient handoffs: standardized and reliable measurement tools remain elusive. The joint commission journal on quality and patient safety, 36(2), 52-61.

30.Rajapaksa, D., Gifford, R., Torgler, B., Garcia-Valiñas, M., Athukorala, W., Managi, S., \& Wilson, C. (2019). Do monetary and non-monetary incentives influence environmental attitudes and behavior? Evidence from an experimental analysis. Resources, Conservation and Recycling, 149, 168-176.

31.Rajapaksa, D., Gifford, R., Torgler, B., Garcia-Valiñas, M., Athukorala, W., Managi, S., \& Wilson, C. (2019). Do monetary and non-monetary incentives influence environmental attitudes and behavior? Evidence from an experimental analysis. Resources, Conservation and Recycling, 149, 168-176.

32.Rose, N. (1998). Inventing ourselves: Psychology, power, and personhood. Cambridge University Press (p.32). 
33.Ryan, R. M., and Deci, E. L. (2000). Self-determination theory and the facilitation of intrinsic motivation, social development, and well-being. American Psychologist, 55, 68-78.

34.Sageer, A., Rafat, S., \& Agarwal, P. (2012). Identification of variables affecting employee satisfaction and their impact on the organization. IOSR Journal of business and management, 5(1), 32-39.

35.Sarwar, S., \& Abugre, J. (2013). The influence of rewards and job satisfaction on employees in the service industry. In the Business \& Management Review, 3(2), 22- 32.

36.Senyücel, E. (2009). Evaluation of SERVQUAL Instrument as Bank Selection Criteria in the Banking Industry: Empirical Evidence from Turkish and Greek Speaking Areas in Cyprus. Banking \& Finance Letters, 1(1).

37.Sun, J. (2013). Employee engagement: How to use recognition and non-monetary rewards to drive employee engagement. Accessed on the 11th June, 2013 at www.hotelexecutive.com/business_review/2961/employee-engagement-how-to-userecognition-andnon- monetary-rewards-to-drive-employee-engagement.

38. Whetten, D.A. \& Cameron, K. S. (2007). Developing management skills. Upper Saddle River, New Jersey: Pearson Prentice Hall.Working Papers No. 012/10

39.Yang, K., \& Kassekert, A. (2010). Linking management reform with employee job satisfaction: Evidence from federal agencies. Journal of Public Administration Research and Theory, 20(2), 413436.

40.http://www.businessdictionary.com/definition/workenvironment.html\#ixzz439roBeNQ. Retrieved March 2, 2016. 